\title{
MaX Weber e Adorno sobre o CONCEITO de Progresso: CONTRASTES dA RACIONALIZAÇÃo TÉCNICA NA MÚSICA E NA PINTURA
}

\author{
Luis Felipe de Salles Roselino ${ }^{1}$
}

Resumo: A revisão que será desenvolvida a seguir foi identificada diante do contraste teórico no tratamento do conceito de "progresso", nos escritos de Adorno e Max Weber, respectivamente, no texto de 1962, "Fortschritt" (Progresso), e no texto de 1917, "Sobre o sentido da Wertfreiheit nas ciências econômicas e sociológicas”. Pretende-se comparar as abordagens, destacando-se os diferentes recursos teóricos empregados, identificando diferenças nos usos conceituais da teoria tradicional e da teoria crítica. O contraste teórico ficará mais nítido, quando comparados os exemplos da história da arte tomados pelos dois autores. Weber utilizava um critério geral para equiparar as obras musicais às pinturas, enquanto Adorno pressupunha algo distinto, seguindo o mesmo referencial, o progresso técnico.

Palavras-chave: Adorno. Max Weber. Progresso. Estética. Música.

\section{INTRODUÇÁO}

Há muitos pontos em comum e uma divergência exemplar, nas abordagens de Weber e Adorno sobre o progresso, particularmente em suas aplicaçóes às produçóes estéticas. À primeira vista, é comum constatar que Max Weber realizava as discussóes teóricas de forma mais sistemática e formalista, pressupondo um princípio de demarcação que opõe o campo lógico e empírico ao valorativo; essa disposição pode vir a contrastar com alguns elementos de inspiração marxiana e se opóe à forma aforística nietzschiana, que influenciou o estilo mais ensaísta de Adorno.

Essas supostas diferenças parecem predispor posiçôes teóricas bem nítidas. De um lado, Weber valorizava, mas não se identificava, com o

${ }^{1}$ Docente no Departamento de Ciências Humanas da Universidade do Estado de Minas Gerais, Frutal, Minas Gerais - Brasil. (1) https://orcid.org/0000-0002-2512-5681 Email: luis.roselino@uemg.br

http://doi.org/10.1590/0101-3173.2020.v43esp.23.p317

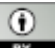

This is an open-access article distributed under the terms of the Creative Commons Attribution License. 
procedimento chamado por ele de "diletantismo", como ficará claro no trecho a seguir: "quase todas as ciências têm algum motivo de gratidão aos diletantes e com muita frequência, sobre pontos de muito valor. Mas o diletantismo como princípio da ciência consistiria em seu fim.” Nesse caso específico, Weber estava argumentando contra a teoria das visóes de mundo e contra certas influências românticas, tal como o trecho que segue confirmará: "quem muito fala sobre 'intuição' não faz mais do que esconder uma distância já perdida de seu objeto, e o mesmo julgamento se aplica, de igual modo, quanto à sua atitude frente aos homens" (WEBER, 1922 [GARS I], p. 14). É justamente essa "distância já perdida” entre sujeito e objeto que coloca às claras como a oposição dos dois pensadores não é tão nitidamente contrastável.

\section{CONSIDERAÇÓES PRÉVIAS SOBRE SUJEITO E OBJETO}

Há certo efeito generalizado que é originário da constatação da incompreensibilidade dos fenômenos humanos, o qual estava voltado a reforçar a fragilidade de qualquer sentido histórico perante a razão, e esse efeito permaneceu, para Weber, como pressuposto negativo a se considerar com ressalvas, pois, se for levado às últimas consequências, como princípio irracionalista, destruiria o próprio projeto científico sociológico. Embora as correntes que criticava fornecessem contribuições consideráveis, elas partiam de pressupostos incompatíveis com o padrão científico por ele idealizado, de modo que, para esquivar-se à questáo filosófica, Weber substituiu a discussão da razão substancial pela instrumental em suas análises, como a leitura de Horkheimer fez patente em "meios e fins".

Adorno é certamente um desses teóricos que soube reconhecer semelhante opiniáo sobre o valor do diletantismo, mas que, diferentemente de Weber, fez uso de suas vantagens sem abrir mão do rigor teórico-crítico por uma apreciação com viés romântico-irracionalista; soube fazê-lo de modo a manter-se coerente ao problema da oposição crítica entre sujeito e objeto. As críticas mais substantivas ao diletantismo e ressalvas de Weber quanto ao método não atingiriam pontos de divergência, os quais tornariam o contraste entre os dois autores mais nítido. Adorno lidava propriamente com os limites do que Weber chamou de "distância já perdida do objeto", sem dispensar a importância de se ater ao objeto, dentro dos limites subjetivos históricos e buscando manter-se a par com os avanços da filosofia moderna. Especialmente em consideração ao "giro copernicano", Adorno propunha, inclusive, um 
“duplo giro copernicano" (MUSSE, 2007), dispondo-se a reconsiderar o sujeito e sua limitação para além da ideia genérica de um sujeito do conhecimento.

Assim, sem abnegar a objetividade do conhecimento, Adorno propiciou uma vantagem possivelmente inédita nesse campo, evitando os limites hipostasiados pela teoria do conhecimento que os tomava pretensamente como limites subjetivos universais, limites eternos e insuperáveis do entendimento, em observância às condiçóes efetivas que nos limitam enquanto sujeitos, a partir do hic et nunc histórico.

Como esse tipo de superação só pode ser considerada dialeticamente, embora Max Weber tenha pagado igualmente seu tributo à teoria do conhecimento de Kant, ele o fez limitando-se aos elementos críticos e analíticos da teoria tradicional ${ }^{2}$. Mesmo enfrentando questôes cujas raízes seriam propriamente históricas, Weber restringiu-se à forma conceitual convencional no seu tratamento e a um modelo particular de ferramenta teórica, as tipologias, para construção de conceitos puros ou ideais. Há marcas do contexto intelectual de quando datam os escritos de Weber, e elas mostram recorrentemente a presença limítrofe de elementos da teoria tradicional como o que seria a melhor alternativa à visão positivista do progresso e, por outro lado, à da decadência, destacando, em sua época, considerável vantagem teórica sobre as correntes dominantes.

Pela leitura da discussão de Weber, é possível notar as ferramentas analíticas da teoria tradicional com a pretensão de produzir um rigor inexistente aos momentos distintos do sentido dialético do conceito de progresso, sentidos que se confundem, manifestam contradiçóes ou pressupóem formas de juízos a priori que falsificariam a interpretação histórica e sociológica. Ao mesmo tempo que falham em captar seu sentido histórico dinâmico, as separaçóes analíticas de sentido serviriam, por outro lado, para identificar e vetar o sentido histórico pouco realista e teleológico positivista. A análise conceitual de Weber serve, nesse sentido, como exato exemplo do tema tratado por Adorno, em seu escrito de 1962, "Progresso", e do quanto é possível avançar criticamente pela teoria tradicional. É justamente esse o objetivo da discussão que se seguirá.

\footnotetext{
${ }^{2}$ A oposição entre teoria tradicional e teoria crítica é aqui significativa, não só segundo sua matriz, no texto de Horkheimer de 1937, mas também em consideração ao "Ensaio como forma" de Adorno. Nesse texto, o autor salienta as limitaçôes das ferramentas analíticas conceituais aqui tratadas: os pressupostos de enumerar e definir revelam-se como limitaçóes diante da dinâmica dos objetos históricos.
} 


\section{TrÊS SENTIDOS DO CONCEITO WEBERIANO DE PROGRESSO}

Se partirmos do escrito de Adorno, o deslindar da discussão também provocaria a aparência de um total desencontro com a proposta de Weber, pois ele afirma que "o conceito de progresso se desfaz com ainda mais facilidade que os demais diante da exigência de especificação daquilo que realmente quer dizer [...]. Quem busca precisar seu conceito acaba, sem maiores esforços, por destruir seu alvo"3 (ADORNO, 1977 [AGS 10.2], p. 617). Weber havia feito exatamente o contrário, o que era vetado no alerta de Adorno; propôs três sentidos específicos e distintos para o conceito de progresso. Em suas palavras: “o 'progresso' engloba em seu sentido: $1^{\circ}$ a mera diferenciação 'progressiva'; em seguida, $2^{\circ}$ o progredir técnico racional dos meios; e, finalmente, $3^{\circ}$ a elevação do valor" " (WEBER, 1922 [GAWL], p. 487).

O primeiro sentido e o mais genérico, (1) a "mera diferenciação progressiva", seria aplicado ao surgimento da variedade de novos elementos. Ele seria verificável, à medida que surgem novos temas nas escolas literárias, novos estilos nas artes plásticas, também novas seitas religiosas, novos partidos, novas facçóes, novas áreas do saber. No capítulo de Economia e Sociedade, destinado aos "conceitos sociológicos fundamentais", Weber apresenta o conceito de diferenciação, em analogia ao sentido orgânico, sugerindo uma possível correlação com a noção de progresso de Herbert Spencer. Entretanto, como a própria fundamentação dessa noção de Spencer tem inspiração nos escritos de C. F. Wolff, Goethe e Von Baer, a inspiração weberiana pode estar em algum lugar entre esses autores. Weber acrescentava a ressalva de que o conceito de diferenciaçáo se aplicaria apenas ao aumento quantitativo na diversidade qualitativa, isto é, que não deveria ser tomado como vantajoso nem desvantajoso, segundo a consideração empírica, e sua constatação não permitiria definir qualquer sentido valorativo sobre suas consequências.

A preocupação de Weber era vetar qualquer tentativa de propor "uma noção unívoca de uma época”; sob esse aspecto, Weber já se distanciava tanto

\footnotetext{
${ }^{3}$ Sempre que citada a edição alemã, a tradução foi feita pelo autor deste artigo. Quando duas versôes forem citadas, isso significa que se seguiu em grande parte alguma tradução e foram feitas pequenas adaptaçóes.

${ }^{4} \mathrm{Na}$ edição de 1922, aparece a expressão "Wertsteigung"; na edição posterior, de Winkelmann, encontramos "Wertsteigerung". Em todo o texto, Weber emprega a expressão Wertsteigerung. Com efeito, não há grande diferença entre as duas, são praticamente sinônimas: Wert significa "valor", Steigung remete a "subida ou elevação" (no sentido topográfico) e Steigerung, "aumento acréscimo de graus, quantidade" etc.
} 
da teoria das visões de mundo como de um sentido teleológico geral. Mais adiante, Weber (1922 [GAWL], p. 480) propunha a seguinte advertência:

[como] em um progresso de "diferenciação" anímica [...] temos externalizaçóes da vida, ocorre que com extrema facilidade elas suscitem a ilusão da diferenciação. [...] Sua aparência ilude muito facilmente e considero de minha parte, o risco da ilusão bastante elevado.

De fato, essa consequência parece um produto do próprio sentido valorativo do progresso, quer dizer, identificar a diferenciação a partir de uma visão que julga no passado um estado de espírito e de coisas mais simples, mais limitado. Ora, essa suposta simplicidade seria, vez ou outra, mais produto da ignorância sobre as condiçóes sociais do passado do que um estado verificável.

A economia feudal nos parece, frequentemente, menos complexa que a capitalista, mas o especialista nesse tema pode bem enumerar dezenas de questôes que não se explicam satisfatoriamente com a ciência econômica moderna. A vida religiosa do início da sociedade estamental pode parecer mais simples e coesa que as complexas relaçôes políticas e hierocráticas do mundo europeu pós-Reforma, mas quem se dedica ao mundo bizantino ou à história dos movimentos que promoveram a "diferenciação", dentro de ordens monásticas, identificaria muitas variaçôes, questóes obscuras e mais pontos cegos nessa origem supostamente "não diferenciada" da vida religiosa.

Como Weber opunha epistemologicamente a limitação do conceito à infinitude da realidade, a ilusão retrospectiva do progresso parece tão inevitável quanto seu sentido é incerto, de maneira que quem observa o "progresso", do presente, acaba sendo fadado a reduzir de modo seletivo e enviesado (einseitig) o passado.

(2) Do progresso como diferenciação, Weber passará ao "progresso técnico corretamente compreendido". O uso terminológico que Weber denominava "correto" é exemplificado pelo que ocorre na história da arte: a evoluçáo técnica pode e frequentemente produz um aumento nos meios à disposição do artista, podendo produzir assim uma diferenciação. Somente a técnica, nesse sentido, nos permite identificar com exatidão o surgimento de um novo estilo:

Somente pelo entendimento correto [richtig] do progresso 'técnico' se avança consequentemente no domínio da história da arte, isso simplesmente porque ele e sua influência sobre a vontade artística mostra 
um conteúdo no transcorrer da evolução artística que é representável por meios puramente empíricos, isto é, sem qualquer valoração estética (WEBER, 1922 [GAWL], p. 482).

Pela maneira como foi definido, esse sentido de progresso diz respeito apenas aos meios e às possibilidades, não ao progresso segundo um juízo de valor que torna uma técnica em particular a fonte das obras mais "belas", "mais perfeitas", "superiores" etc. Os juízos de valor estéticos não devem ser confundidos com a constatação empírica do surgimento de novos meios empregados, mesmo que os dois sentidos de progresso tendam a se confundir. Do mesmo modo, se compreendido de forma conceitual precisa, o progresso técnico remeteria apenas aos meios de que dispóe e não aos fins, o que o tornaria separável de toda valoraçáo sobre o que é superior ou decadente, de um ponto de vista estético ou moral. Esse é um conceito-chave para Weber, pois se dissociaria mais facilmente dos juízos de valor que falseariam a análise histórica.

(3) O último sentido tratava especificamente da mistura da constatação empírica com juízos de valor, como pode eventualmente ocorrer nos dois outros conceitos de progresso, se não forem definidos de forma rigorosa. Este caso ocorre sempre que o progresso passa a ser confundido com o ideal de um acréscimo de valor, ele passa imediatamente a ser problemático e a impossibilitar o trabalho do historiador em geral, como se dá com o historiador da arte quando sua análise é deturpada por afinidades com determinadas escolas, valores estéticos ou predileçôes particulares. Se o primeiro sentido é definido por meio do reconhecimento das categorias quantitativas e qualitativas, o segundo sentido pressupóe as categorias de meios e fins. Fica, portanto, evidenciado o primado do sujeito kantiano, disposto segundo categorias e, no terceiro caso, faculdades de julgar.

Nos pontos em que a problematização e consideração teórica weberiana se cruzam com a teoria crítica, nota-se que, uma vez que o peso da análise se colocava mais no objeto ${ }^{5}$, conforme suas condições históricas, se sacrificavam os ideais de "clareza e distinção"; ao contrário, quando entra em cena uma

5 Sem poder detalhar essa discussão paralela, é interessante notar que certas propostas conceituais weberianas desafiavam a forma conceitual tradicional, porque, tal como ocorre com os "tipos puros de dominação", um conceito pode tomar a forma do outro. Aqui teríamos, segundo Adorno (2007, p. 287), a "prioridade do objeto" desafiando o esquema teórico weberiano. Ao contrário, a deturpação e a confusão dos sentidos de progresso em Weber parece ter um fundamento tomado mais exclusivamente do "primado do sujeito", expondo as divergências teórico-críticas dos dois autores. 
teoria subjetivista da faculdade de julgar, predominava a forma analítica da teoria tradicional, reforçando os aspectos das tipologias como meras ferramentas limitadas diante da infinitude da realidade histórica.

Há um caso de exigência de exatidão conceitual muito próximo ao abordado. Em uma conferência da Sociedade Sociológica Alemã, em 1910, Weber criticou o conceito de "técnica" (Technik) de seu colega Staudinger e exigia reiteradamente um conceito "mais específico", pois o sentido por ele pretendido "poderia aplicar-se ao ato de andar, comer, e qualquer tipo de procedimento"; em seguida, questionava: "mas será que realmente se aplicaria à máquina tecelá, à fiandeira e a todos os trabalhadores sem formação que as manipulam?" (WEBER, 1911, p. 97) - e, por três ou quatro vezes, repetiu, nessa conferência, sobre a necessidade de "forjar" um "conceito mais específico de 'técnica". Isso permite observar, em Weber, os limites do sentido do progresso "técnico" para além dos domínios da história da arte.

Ocorre tanto para Weber como para Horkheimer que, de um lado, se encontra o sentido genérico iluminista de técnica que se funde com o ideal de dominação da natureza, por meio da experiência e pela previsão ${ }^{6}$; por outro lado, sua realidade, os que operam de fato as máquinas se encontravam nas condiçóes de dominados e de não possuidores de domínio teórico e real sobre elas. Assim, ao mesmo tempo em que se furtava a definir o sentido específico de técnica, Weber se apegava à evidência das contradiçôes produzidas entre seu sentido inexato e genérico e seus sentidos particulares:

[...] eu não gostaria de definir esse conceito aqui nessa ocasião - contudo, considero que se não reduzirmos esse conceito, diferente do que tem ocorrido aqui, ele irá se esvanecer tão logo o atribuímos ao 'espírito' dos homens (WEBER, 1911, p. 97-98).

A particularidade histórica como crivo weberiano era inimiga da forma conceitual positivista e idealista. Diante dessa dificuldade, o próprio Weber se queixava, como leitor da Miséria da Filosofia, dizendo que, de acordo com sua leitura, "Marx não deu uma definição do conceito de técnica" - e acrescentava: "as revoluçóes [Wendung] puramente tecnológicas permanecem obscuras, como outras questôes tratadas por Marx” (WEBER, 1911, p. 96), manifestando sua frustração por não encontrar a diferenciação progressiva das

${ }^{6}$ Como na apresentaçáo do próprio conceito weberiano de desencantamento, "significaria, em princípio, que alguém poderia dominar todas as coisas por meio da previsão" (WEBER 1922 [GAWL] p. 536) 
técnicas antigas em relação às inovações nas corporaçôes de ofício e dessas à revolução tecnológica do vapor e do carvão ${ }^{7}$.

Poucas décadas depois dos escritos de Weber, será patente a vantagem desses aspectos segundo a necessidade que fez com que Marx tratasse os conceitos hegelianos em função de categorias históricas ${ }^{8}$. No momento em que Weber identificava o problema, sua postura reproduzia o veto de um leitor que primava mais pelo rigor conceitual e se ateve à teoria tradicional o quanto possível. Assim, a forma crítica e analítica seria de fato a mais vantajosa para os casos históricos, na medida em que captaria o sentido particular de cada contexto; as inevitáveis contradiçóes deveriam ser revisadas após a dissecação de cada sentido contido no objeto (positivamente pensado) ou pretendido pelo sujeito (criticamente depurado); o que visava eliminar qualquer possibilidade de uma teleologia impossibilitava, ao mesmo tempo, uma versão materialista da história orientada pela superação das condiçôes presentes. A real ameaça para Weber não seria, no entanto, a imprecisão em si, pois todo trabalho teórico exaustivo sabe que propóe uma tarefa impossível. Ela se identificaria, mais propriamente, com os juízos de valor que vinham misturados nos sentidos produzidos e que atribuiriam algo específico dos valores subjetivos ao objeto histórico, falsificando a análise.

\section{DELINEAÇóES do PROGRESSO NA ARTE E NA TÉCNICA}

Havendo caracterizado a teoria de Weber segundo os pressupostos da teoria tradicional, passemos para o exemplo que une e separa a perspectiva dos dois autores. As marcas claras dessas diferenças se encontram nos escritos que fundamentam a presente discussão quanto à questão estética, nos casos da música e da pintura. Nelas, como se pretende destacar, é possível identificar as

\footnotetext{
$7 \mathrm{O}$ próprio Marx, nesse texto, criticava a divisão do trabalho em sentido genérico e anistórico, pelo conceito de Adam Smith tomado por Proudhon: "o trabalhador só poderia chegar à ciência e consciência do alfinete" (MARX, 1896, p. 196. 200). Na verdade, Marx não priorizou qualquer definição clara e historicamente precisa de alguma técnica em particular, somente a descrição das "condiçóes históricas" que a possibilitaram em seu sentido "humano" e, embora recorresse a dados históricos exatos, não o fazia para construir definições pontuais, mas para fundamentar sua crítica à visão idealista da História. Sobre a diferença entre a historiografia e a concepção histórica de Marx, ver as notas de Benjamin sobre o conceito de História. Sobre o uso terminológico em Marx ser indefinido e variar seu sentido, ver o início do primeiro capítulo de Ollman (1973).

${ }^{8}$ A referência a "conceitos e categorias" remete à parte fundamental da Dialética negativa, de Adorno. A passagem mais difundida sobre essa alteraçáo de conceitos em categorias encontra-se em Razão $e$ Revolução, no primeiro parágrafo da parte I, "Fundamentos da teoria dialética da sociedade".
} 
diferentes ênfases dos primados (Vorrange) do sujeito e do objeto9 9 . O trecho de Adorno em que se focará a análise, a qual é mais propriamente uma discussão que uma análise, é o seguinte:

Todos os progressos nos domínios culturais concernem ao domínio material, à técnica. Nem mesmo o conteúdo de verdade do espírito é indiferente a isso. Um quarteto de Mozart não é apenas melhor elaborado do que uma sinfonia da escola de Mannheim, mas ocupa posição superior também no estilo enfático de elaboração melhor, mais justa. Por outro lado, é problemático se com o desenvolvimento da técnica da perspectiva a pintura da alta renascença realmente superou a supostamente primitiva (ADORNO, 1977b [AGS 10.2], p. 634).

Tomemos a passagem por três aspectos que estáo relacionados: (a) Weber e Adorno compartilham, no geral, seu ponto de partida: a técnica "todos os progressos nos domínios culturais concernem ao domínio material, à técnica", conforme supracitado e semelhantemente, segundo Weber, "somente o entendimento correto do progresso 'técnico' permite o domínio da história da arte”, mas com a ressalva que os difere - "como um conteúdo representável por meios puramente empíricos, isto é, sem qualquer valoração estética” (WEBER, 1922 [GAWL], p. 482); Adorno parece propor uma valoração.

(b) Há ainda outra clara convergência inicial, a qual faz inclusive levantar a suspeita de Adorno estar citando Weber indiretamente: "é problemático se com o desenvolvimento da técnica da perspectiva a pintura da alta renascença realmente superou a supostamente primitiva"; esse trecho da última citação de Adorno apresenta plena equivalência com o que Weber propunha: "obras de arte com técnicas, certamente mais 'primitivas' - figuras sem p. ex., o conhecimento pleno da perspectiva - possibilitam [vermögen] esteticamente a mesma plenitude, sendo absolutamente igualáveis às criadas sobre o solo de técnicas racionais" (WEBER, 1922 [GAWL], p. 485).

As considerações gerais são semelhantes, porém, divergem em questões particulares. Se, por um lado, Weber se atém ao caso geral, a partir do exemplo da técnica da perspectiva, no que ambos concordam, (c) Adorno, por outro lado, propóe um caso em que a regra não se aplicaria, no qual não se teria dúvida ao identificar aspectos qualitativos superiores, com base em uma maior exatidão na produção musical do século XVIII, e seu juízo

\footnotetext{
9 Essa discussão foi norteada pelo artigo "Materialismo e primado do objeto em Adorno" (MAAR. 2006); sem a compreensão desse sentido, tanto o conceito de progresso como a relação entre técnica e história da arte tendem a ser malcompreendidas.
} 
parece fundamentar-se em fatores estritamente técnicos. Haveria, segundo ele, evidente superioridade técnica entre as composiçóes de Mozart e as da Escola de Mannheim.

Acompanhemos a diferença mais de perto. Max Weber explicava que "a criação de novos meios técnicos significaria de início apenas a multiplicação da diferenciação e, no sentido da elevação do valor, unicamente a possibilidade da multiplicação do 'enriquecimento' da arte." Nesse trecho, fica clara a separação da valoração estética e do progresso técnico. Por isso, uma obra de arte sem o conhecimento técnico da perspectiva não se mostraria, esteticamente, mais limitada ou inferior; o desenvolvimento técnico suscita mais possibilidades, em um sentido específico (pintar com ou sem a técnica, em pleno uso ou com transgressôes intencionais), mas não determina o curso do desenvolvimento estético para o "melhor". Nessa passagem, Weber grifou especificamente o radical "possível” (Möglisch) da expressão "possibilidade" (Möglischkeit), para enfatizar que o progresso técnico poderia, eventualmente, viabilizar, mas não traz em si os elementos práticos capazes de realizar o enriquecimento estético. É possível supor aqui um sentido de autonomia que é negado; quanto à consideração causal, ela será sempre condicionada historicamente pela técnica, pelos meios de que dispóe. Weber frisava a necessidade de se reconhecer os seus "a prioris", no sentido de sua heteronomia e não autonomia. ${ }^{10}$

Sem dúvida, a técnica da perspectiva promoveria uma diferenciação estética, pois agora o artista, o gênio criador renascentista, teria uma nova ferramenta inovadora para "escolher"; entretanto, na prática, não se verifica escolha alguma, porque ela se torna a regra, uma imposição da técnica sobre a forma. A régua que esquadrinha de forma exata também limita a pintura às suas dimensões, como a métrica na poesia. Logo, não vemos aumentar tanto suas possibilidades, pois, em certo sentido, a arte primitiva representava as formas com maior liberdade, podendo aumentar as proporçôes do que está distante, expor o que estaria oculto atrás de uma barreira física ou da quina de uma parede.

\footnotetext{
${ }^{10}$ Isso contraria Habermas: "Max Weber leu a racionalização cultural, segundo a ciência e a técnica moderna, ancorado pelo princípio na arte, no religioso, de diretrizes éticas autônomas [autonomer]" (HABERMAS. 1988, p. 228) - e acrescentava: "Adorno seguiu essa linha [weberiana], analisou e demonstrou que a evoluçấo artística vanguardista se torna processo e meio reflexivo de produçáo da arte [...] embora ele tenha permanecido sobremodo cético frente à 'autonomia do método diante das coisas [Sache]'. Ao contrário, o que Weber chamava de "relativa autonomia” parece corresponder à mesma ponderação de Adorno. Sobre esse tema, ver Klein (2019).
} 
A perspectiva suscitou a preferência para que os retratos da Ceia do Senhor passassem a adotar a composição com todos apóstolos assentados de um só lado da mesa (como na Última ceia de Da Vinci e várias versões do século XVI), assemelhando-se mais a uma encenação do acontecimento do que ao se sentar à mesa, que era retratado antes com naturalidade. Antes das técnicas da perspectiva, era possível expor a mesa em toda sua volta, sem a sobreposição dos principais elementos, sem a redução das proporções da figura central ao fundo (como nas versóes góticas de Duccio di Buoninsegna ou Jaume Huguet, dos séculos XIV e XV). Em certo sentido, havia mais opçóes para a composição e para as proporçóes dos elementos hierarquizados, mesmo que dispondo de "menos técnicas" de composição espacial. O progresso como diferenciação é claramente visível nesse caso, quando identificamos a continuidade dessas características "primitivas" na arte sacra das igrejas orientais do século XVI, em forte contraste com a dos países renascentistas, cada qual progredindo segundo diferentes padróes, com e sem a nova técnica.

Como foi visto, a diferenciação e o progresso técnico são entendidos conforme a "possibilidade" e, frisemos, não mais que isso, "de um enriquecimento do valor estético". Assim, Weber acrescentava a seguinte opinião: "de fato ele", no caso, o progresso dos meios técnicos, "apresentou frequentemente o efeito inverso, o 'empobrecimento' do sentimento das formas [Formgefühls]". Esse tipo de opinião, evidentemente, não poderia ser emitido por Weber, sem a típica ressalva de que, "[...] contudo, para a consideração empírico-causal, a mais importante representação universal do momento progressivo da arte, é a alteração da 'técnica' (no sentido mais elevado da palavra)" (WEBER, 1922 [GAWL], p. 485). Weber grifa o termo "causal" para reforçar sua consideração de que o fenômeno, tomado pela causalidade histórica, não nos enseja comprovar esse "empobrecimento" da forma, embora nos permita supor essa possibilidade como mais marcante de acordo com determinados padróes técnicos, segundo objetos em particular.

Desse modo, mesmo reconhecendo uma tendência muito marcante do domínio técnico como causador do empobrecimento estético, a constatação de Weber apresentava-se, de fato, muito cuidadosa em não recair no erro oposto à valoração estética que favoreceria a obra de arte tecnicamente mais evoluída: o erro de considerar toda arte que se serve do domínio técnico mais avançado como decadente, o que seria também um juízo de valor. Entretanto, Weber não poderia formular um quarto sentido de progresso, voltado para a ideia de decadência, por motivos evidentes: a teoria tradicional tem horror 
à contradiçãa. $\mathrm{O}$ sentido de progresso que escapa às definiçóes de Weber remete àquele do anjo da história de Walter Benjamin. Vemos surgir uma espécie de vazio dentro do esquema terminológico de Weber, logo que ele cita a elevação de valor como o sentido mais problemático do progresso e veta o reconhecimento das formas decadentes pelo mesmo princípio, náo justificando o motivo de o mesmo critério estar sendo aplicado ao que se dá, na verdade, segundo juízos opostos. O juízo do sujeito que opera a valoração positiva ou negativa pode dar-se, em princípio, pelo mesmo tipo de operação, mas quanto aos três sentidos do conceito de progresso, não há lugar para sua correlação com a decadência.

Se seguirmos essa constatação de Weber sobre o empobrecimento do mundo sensitivo que as formas projetam para além de si, passando pela "Obra de arte na época de sua reprodutibilidade técnica", de Benjamin, até a concepção da indústria cultural, nota-se como as constataçôes de cada autor sugerem certa proximidade, entendem o progresso criticamente, pois compreendiam a técnica como uma força que se coloca por sobre os homens, que os conforma segundo seu ritmo e seu esquadro, em meio à padronizaçáo crescente que tudo reduz ao saturado ar comum das variaçóes do mesmo padrão. $^{11}$

Como a aplicação da teoria de Weber acaba trazendo de fora de seu esquema conceitual a ideia de decadência, sua disposição crítica também igualava formalmente a ideologia da sociedade industrial aos elementos ideológicos que tomam consciência de sua crise, tornando a crítica cega em face do que é ideologia e o que é um protesto contrário a ela. Como não podia separar seus sentidos conceituais pelas ferramentas da teoria tradicional, ele acaba reduzindo todas diferenças reais a meras questóes de gosto ou preferência particular, isto é, subjetivando as diferenças.

São muitos os casos em que essa aparente equivalência de juízos críticos pode ser enganosa. Adorno colocava essa mesma questáo, ao propor a discussão a propósito da "regressão da audição", a qual começava, justamente, reconhecendo o lugar comum da ideia da "decadência do gosto musical",

\footnotetext{
${ }^{11}$ Weber buscou distanciar-se da visão romântica, que carecia ou falhava em identificar um sentido para esse progresso; embora pensada em sentido imanente, a refutaçáo da teleologia histórica não o conduz ao niilismo. Mesmo que formado com valores advindos da crise dos ideais iluministas, a visão de mundo predominantemente valorativa tinha para ele o efeito de falsificar a análise, pois a visão do presente que ela permite, por mais realista que pareça, contradiria a compreensão conceitual da dinâmica que a leva, o "redemoinho das asas" de Benjamin, "o vento que o impele para longe", sempre olhando o caos do passado ao mesmo tempo que o produz (BENJAMIN, 2012, p. 14).
} 
desconfiando do que pode não passar de uma murmuração ou de um conservadorismo. A advertência de Weber quanto aos juízos de valor só valeria se aceitássemos o fundamento epistemológico subjetivista de sua teoria dos valores; não valeria, se considerássemos que o fundamento está dado em vista de causas históricas e culturais, conforme seu papel ideológico. Tampouco Adorno lançou ao ar sua predileção por Mozart à Escola de Mannheim: não era uma mera questão de gosto, porque ele apontou elementos puramente técnicos que parecem fazer da música um caso distinto das artes plásticas. A questão da perspectiva na pintura e da racionalização da música deve ser lida paralelamente ao texto "sobre algumas relaçôes entre música e pintura" e, em geral, os Escritos musicais, juntamente à discussão sobre o conceito de progresso, para que não se confunda a prioridade do objeto com juízos estéticos.

Ao tratar da música, Weber incluía também nesse campo o progresso técnico como guia, "todos esses são 'progressos' dos meios técnicos da música que hão condicionado fortemente sua história”, e acrescentava: "esses componentes da evoluçáo histórica podem e têm de propor o desenvolvimento histórico empírico, sem supor, para si mesmo, uma valoração estética das obras de arte musicais." Embora soubesse que era quase inevitável expor qualquer juízo, insistia que "o progresso técnico, com certa constância, presta serviços altamente insatisfatórios para a valoração estética. $\mathrm{O}$ que orienta seu interesse: o objeto a ser esclarecido historicamente, é a história musical heterônoma [Musikgeschichte heteronom], através da qual se dá esse caráter estético significativo" (WEBER, 1922 [GAWL], p. 484-485). Assim, não haveria a menor diferença em relação às artes plásticas, nesse outro caso, o conceito de progresso não ultrapassa o reconhecimento da técnica, que não é mais que um meio, assim, os objetos em questão, as produçóes musicais, não devem ser tomados como esteticamente superiores nem inferiores, ainda que sejam "mais avançados" tecnicamente. Como o conceito de técnica se reduz aos meios empregados e é ele que guia a análise weberiana, nenhum critério estético deve sobrepor-se ao sentido captado conceitualmente.

No fundo, qualquer juízo estético seria o mesmo, se vinculado à faculdade de julgar de um sujeito genérico; mesmo sendo relativo a valores, ele ao fim deve recorrer à crítica no sentido kantiano, reduzindo o objeto e separando os valores envolvidos. Para Adorno, por outro lado, o objeto não apenas dita regras previstas pelo sujeito, mas o sujeito, em seu sentido histórico, pode e deve subvertê-las. 
Nos escritos teóricos de Weber que pretendem estar além da crítica romântica, como o sujeito é apenas uma ideia geral que dá suporte a sua teoria do conhecimento, deve recair nele apenas a falha em compreender propriamente seu objeto, o qual, sem dúvida, aflora aqui e ali, porém, que é tratado passando ao largo do problema histórico e sociológico, segundo Adorno, de que alguns objetos são também sujeitos. Quando Weber pressupunha que o progresso teria dois ou três sentidos, ignorava que eles nascem de contradiçôes de sentidos que espelham as contradiçóes da consciência histórica dos mesmos sujeitos que os produzem. Se sairmos do recorte apenas teórico do sujeito transcendental kantiano, as limitaçóes que pareciam ser sua exclusividade conceitual se mostrariam relativas também à dinâmica dos objetos, incluindo os agentes, sujeitos históricos que não se reconhecem enquanto tais. Vemos, então, o conceito de progresso tomar forma a partir desse problema: "é tolice contestar o progresso por ele ainda não estar totalmente certo de que seus objetos são os sujeitos" (ADORNO, 1977 [AGS 10.2], p. 632).

Tanto a visão mítica do esclarecimento quanto a sua crítica romântica se deparariam com a mesma limitação, pois falham em identificar as raízes históricas do conceito que denunciam ou ao qual buscam conformar-se; o único sentido que seria possível para esse conceito derivado da "não razão" das condições históricas, seja pela visão mítica, seja pela noção de razão instrumental que a esvazia de sentido, parece vir de fora, como natureza ou destino, uma vez que provém dos homens apenas enquanto objeto. A limitação teórica se dá, pois "[...] em nada se abre máo do primado ${ }^{12}$ do sujeito" (ADORNO, 1977 [AGS 10.2], p. 624-25), espelho da tentativa burguesa frustrada de dominar o caos da dinâmica social, ao mesmo tempo que é dominada por ela, pelo mercado, pelos interesses particulares; a natureza se converte vez ou outra nessa máscara ideológica de não-sujeito que somos. Weber se distancia dos conceitos filosóficos, todavia, não de suas aporias ${ }^{13}$, ou se domina a natureza

\footnotetext{
${ }^{12}$ Nesse caso, a expressão é Primat des Subjekts que precede a noção de Vorrang des Objekts, prioridade ou primado do objeto, expressão recorrente na Dialética Negativa. O termo Vorrang será aplicado tanto a sujeito como a objeto, contudo, a expressão Primat não cai em desuso: parece permanecer referindose apenas ao sujeito do conhecimento, possivelmente, dissociando seu uso do sentido de Sujeito que deve se constituir historicamente.

${ }^{13}$ Esse seria o segredo da história universal que reforça o único sentido possível do propósito da natureza, uma vez que "o 'propósito' $[A b s i c h t]$ não poderia ser pensado de outro modo, senão havendo conferido razão à própria natureza"; no original, a expressão $A b s i c h t$ é a mesma do título do escrito de Kant, traduzido para o português como "ponto de vista cosmopolita"; trata-se do "propósito cosmopolita" que fundamenta a ideia filosófica de história universal kantiana. Essa concepção conduz a uma lógica que beira o absurdo, "na medida em que ela é absoluta e não meramente constituída, se buscamos dominar a natureza o fazemos movidos pelas forças contraditórias originárias dela mesma
} 
ou se é por ela dominado; o conceito de natureza praticamente desaparece, mas náo sua sombra: o diagnóstico do presente como um destino inevitável que leva à resignação.

Como somente mediante o sujeito do conhecimento é possível falar de um objeto em geral, Weber igualava as produçóes estéticas plásticas e musicais, diferentemente de Adorno, pois fixava as bases de sua teoria, pressupondo as produçôes estéticas em geral ${ }^{14}$. Por outro lado, para Adorno, a pintura e a música poderiam apresentar paralelos, não como objetos em geral, mas como possuindo as mesmas marcas históricas de seu presente. Mesmo quando Klee tenta expressar a polifonia pela sobreposição, utilizando a transparência de técnicas de aquarela e de desbastação, cada produção estética se mantém fiel aos elementos particulares de sua racionalizaçáo, e a tentativa de superação na criação de técnicas é mais teórica e simbólica do que efetiva, produzindo somente um Motiv, claramente distinto das tentativas de Kandinsky. Há, fenomenologicamente, uma assimetria entre pretender ver o som nas pinturas e em quase não ouvir a la note bleue de Chopin ou ouvir a luz nas notas de Wagner. Para Adorno, diferentemente da música, na pseudomorfose da pintura seu produtor deve abrir mão da síntese pela ilusão do tempo (ADORNO, 2006, p. 638-639), de sorte que as categorias espaciais e temporais permanecem irredutíveis em suas formas de apreensão histórica.

O problema da postura de Weber é que, quando fundamenta subjetivamente sua crítica à visão positivista simplista do progresso ou mesmo à visão romântica da "[...] 'irracionalidade' que as pessoas parecem compartilhar por completo com os animais”'15 (WEBER, 1922 [GAWL], p. 132), ele dá a questão por resolvida, em termos estritamente teóricos, ao mesmo tempo em que falha em identificar as raízes históricas do problema, o sentido prático de tal limitação. Distintamente da visão histórica cosmopolita, para Weber, a história não deve prever qualquer sentido, da natureza e da história não

e que igualmente nos domina". Adorno explicava como no conceito kantiano de progresso "a estática [Statik] do conceito de natureza é função do conceito dinâmico [dynamischen] de razão" (ADORNO, 1977 [AGS 10.2], p. 624-625). No original, estática aparece como substantivo e dinâmica como adjetivo.

${ }^{14}$ Embora esse tipo de postura weberiana se destaque mais nos escritos teóricos (Wissenschaftslehre), nos textos históricos e sociológicos, Weber priorizava o sentido particular, histórico dos objetos, separando teoria e prática. Adorno relaciona teoria e prática, ao tematizar a diferença entre a pintura e a música, no final do terceiro volume dos Escritos musicais e, novamente, na parte final de "teoria da nova música".

15 "irracionalidade' que as pessoas parecem compartilhar por completo com os animais, em sua real busca do santuário da 'pessoalidade'. Tal é o sentido romântico que está por trás do 'enigma da personalidade'." 
se pode derivar uma moral, uma finalidade, um télos, pois só teriam valor subjetivo enquanto ideia; também não faz sentido amaldiçoá-la ou decretar seu fim, pela mesma limitação contida no sujeito. A capacidade de julgar o bem e o belo vêm junto com a incapacidade de compreender propriamente a realidade por esses meios dogmáticos.

Pela ótica de Adorno, dar prioridade ao objeto é dispor-se a que seu sentido seja captado por sua dupla dinâmica (objetiva e subjetiva), e todo ideal em que está envolto, seja positivamente, seja negativamente referido, passa a representar a marca mais clara do estado de espírito histórico do qual se parte. As ferramentas críticas de Weber buscavam eliminar a interferência do sujeito do conhecimento na apreciação dos objetos, enquanto as de Adorno visavam a extrair também dele seu sentido histórico dialético. $O$ início da exposição de Adorno sobre a "categoria progresso" problematiza tanto seu tratamento "positivo como negativo", pois ambos estariam limitados, historicamente e conceitualmente. Diferentemente de Weber, que resgata

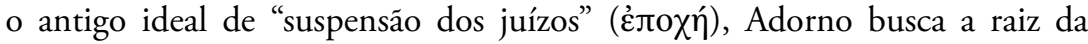
limitação aparentemente teórica que está por trás da visão crítica, bem como da visão comprometida com os valores contraditórios do progresso, de modo que eles revelem os sinais de seu momento histórico.

\section{Consideraçóes Finais: dos limites CONCEITUAIS Às CONDiÇóes SUbJetivaS}

Ao invés de separar analiticamente os sentidos e depurar o objeto daquilo que se atribui às faculdades de julgar, Adorno segue a técnica, a ponto de fazê-la desaparecer como conceito historiográfico específico, para depois ser recolocada no grande quadro histórico redobrada de sentidos, subjetivo e objetivo: "A tecnificação da arte é provocada não menos pelo sujeito, pela consciência desiludida e desacreditada da magia enquanto véu, que pelo objeto, isto é, pelas relaçôes internas de como as obras se devem organizar." Aqui está a chave para diferenciar os dois casos estéticos apontados no texto de Adorno sobre o progresso: a necessidade histórica que se impóe ao sujeito, respeitando as exigências do sentido histórico específico da técnica; a necessidade que reside propriamente no objeto também responde às mesmas exigências técnicas: ambas são históricas, porém, uma pela sua condição particular, outra por ser também uma forma de externalização (Entäußerung) da consciência e da vontade; nenhuma se dá segundo "normas abstratas atemporais" (ADORNO, 1983, p. 75; 1977 [AGS 7], p. 94-95). Uma vez que traz as marcas históricas, 
tanto no sujeito como no objeto, permitem reconhecer os sinais dos meios de dominá-las e até subvertê-las. Nota-se, então, como as condições subjetivas e objetivas não coincidem totalmente, embora se confundam.

Um desenvolvimento e um enriquecimento que se deem sem o uso da perspectiva são perfeitamente imagináveis, embora historicamente, diante de todo meio intelectual que engendra os ideais renascentistas, isso se mostraria absurdo; a elevação do artista ao nível de um experimentador e de um doutor produziu nas obras o sentido particular dessa intelectualização e racionalização. Embora o caso da música não seja tão diferente, o sistema tonal e as formas de racionalização técnica a ela inerentes tornam difícil imaginar, na altura do século XVIII, outro sentido mais elevado que não o existente entre as produçóes da escola de Mannheim e as de Mozart, apontado por Adorno, segundo imposições meramente formais em meio à dialética entre quem é dominado e quem domina a técnica. É difícil diferenciar os casos, como desde Kant é inviável pensar sujeito sem objeto, no entanto, cabe compreender como suas necessidades não se igualam. A música tem suas soluções no princípio interno, como na aritmética, e não espacial, como nas intuiçôes geométricas. ${ }^{16}$

Adorno toma o contraste mais problemático, para indicar o sentido próprio de primado do objeto, assegurando que seu sentido seja histórico e náo apenas limitado ao objeto, que as necessidades próprias da produção da obra de arte sejam vistas como produzidas e não pela reificação das condiçóes de produção das mesmas, por isso, adverte, no caso mais controverso:

Se no início da Renascença alguém considerasse usar o fundo dourado em prejuízo à perspectiva, isso não seria apenas reacionário, mas objetivamente inverídico [unwahr], significaria ir contra a própria lógica de suas exigências; uma vez que o que a torna inteligível é justamente aquilo que se desenvolve de seu progresso (ADORNO, 1977b [AGS 10.2], p.634).

Mesmo no caso em que o objeto tomado isoladamente não deixe claro o sentido de sua dinâmica, o quadro histórico abrangente define sua necessidade aparentemente intrínseca. O progresso técnico tomado em sentido "puro" pode apontar com clareza certos caminhos, mas, em muitos casos, contrariando a ideia geral de Weber, ele não comportaria por si só a

\footnotetext{
${ }^{16}$ Adorno remete a esse sentido kantiano e o aplica às diferentes produçóes artísticas, a música e a pintura, seguindo o Laocoonte de Lessing (sobre essa influência, ver: SOCHA (2019); DUARTE (2009)). Além disso, não podemos desconsiderar o tema rousseauniano da música como arte experienciada internamente, ligada diretamente aos sentidos internos, tema que encontra ecos em Hegel e Schopenhauer.
} 
necessidade histórica que o impulsiona e, como reconhecia Weber, com alto risco de ilusão. O que define o caminho das obras de arte renascentistas é o que as separou de sua origem como obra sacra; é, aliás, o que produz o novo sentido de "obra de arte", sua nova "aura" prestes a ser perdida, nos termos de Benjamin, ${ }^{17}$ mediante a crescente padronização e reprodutibilidade técnica. O absurdo do que é proposto no exemplo de Adorno sobre o "fundo dourado" não segue uma lógica intrínseca do objeto em si, nem um sentido técnico puro que seria dissociável de sua necessidade histórica objetiva.

O desencantamento, conceito profundamente weberiano, promovera em Benjamin o reconhecimento da nova "teologia da arte", L'art pour l'art. O culto das obras de arte conduziu igualmente ao ideal de autenticidade e à sua destruição pela reprodutibilidade técnica que recai no fetiche, no aparente desprendimento de seu hic et nunc, uma vez que seu produtor e suas condições parecem tão alheios à obra como se tornou a relação do operário que manipula as máquinas e seu produto final. Embora o desencantamento tenha exposto as consequências valorativas do progresso intelectual, como vimos, Weber impunha restriçôes à pretensão de se construir uma visão geral de uma época, por ser passível de ilusão intelectual. Benjamin e Adorno tomam esse caminho, mas não à maneira das teleologias idealistas, nem da visão romântica, porque possuíam certas diferenças que expóem melhor o caso de Adorno diante de Weber, e é por essa chave benjaminiana que Adorno desdobra o sentido da técnica como limitadora, entretanto, como passível de ser dominada e transgredida. Tal postura frequentemente é confundida com um juízo de valor.

A divergência entre Benjamin e Adorno se enuncia no ponto no qual o primeiro interrompeu sua análise histórica:

[...] o defeito da grandiosa teoria da reprodução de Benjamin é que as suas categorias bipolares não permitem distinguir entre a concepçáo de uma arte desideologizada até ao seu estrato fundamental e o abuso da racionalidade estética para a exploração e a dominação das massas (ADORNO 1983 p.71-72 1977a [AGS 7], p.90).

\footnotetext{
${ }^{17}$ No trecho de Adorno da página anterior (Teoria Estética), há uma possível menção a esse tema: "pela desconfiança contra a magia enquanto véu" provavelmente remete ao seguinte trecho de Benjamin: "Despojar o objeto de seu véu, destruir a sua aura, eis o que assinala de imediato a presença de uma percepção [...] graças à reprodução, consegue estandardizar aquilo que existe uma só vez”. Perder a "aura" conduz tanto ao sentido imagético como poético (Baudelaire) de uma figura sacra que se humaniza (BENJAMIN. 1975, p. 15).
} 
Se a técnica, para Weber, era apenas meio, um meio particular, para Benjamin, é indissociável de suas forças contraditórias, tomando a forma de uma dinâmica que limita a teoria náo-filosófica, uma vez que toma elementos antinômicos como uma constante, em seu momento histórico.

Em contraste com o caso das artes plásticas, Adorno sugere que alguns aspectos estéticos da composição da música apresentam essa necessidade histórica quase totalmente reduzida diante de necessidades puramente técnicas do estado de seu progresso. As diferenças se aniquilam, quando nos encontramos, nos casos mais problemáticos: a necessidade histórica mais abrangente estaria presente mesmo em algo que não nos pareça necessariamente "histórico". O simples reconhecimento das necessidades intrínsecas não vem a significar que está justificado o processo de reificação dessas produções e, embora os objetos se mostrem como coisas dotadas de uma legalidade própria, as mesmas condiçôes históricas que a possibilitaram não esgotam as necessidades a que serve uma produção estética particular. Elas estão dadas na constelação que engloba seu sentido histórico, não de modo compreensível exclusivamente pelos seus elementos técnicos, nem apenas pelo estado histórico em que se encontram.

Contudo, diferentemente da produção de bens materiais da sociedade capitalista, a relação entre esses dois elementos pode ser dada de maneira mais ou menos consciente. Aliás, distintamente da produção industrial e da indústria cultural, que lhe é muito semelhante, algumas produçóes estéticas podem adquirir um elevado grau de consciência e caminhar para a ruptura, tanto estética quanto das limitaçóes de seu estado de espírito, pois são ao mesmo tempo produçóes ideológicas e formas de consciência de suas condiçôes. No entanto, toda ruptura tende a ser meramente estética, não produzindo por si só efeito prático.

$\mathrm{Na}$ música, ocorre que, por vezes, o domínio mais elevado da técnica conduza os objetos à sua transgressão comedida, desde que ela seja feita demostrando o perfeito domínio dessa técnica, como, em Mozart, a unidade se consagra na "quebra da unidade" pelo pleno domínio da técnica, ao contrário de uma limitação a ela: "[...] o compositor, que fora elogiado, antes de tudo o mais, pelo rigor formal, [...] admite as tendências centrífugas de modo a quebrar o rigor da construção" (ADORNO, 1983 p. 162). Tem-se algo semelhante nos reflexos dos espelhos de Velázquez. Algo mais extremado parece ocorrer nas artes plásticas contemporâneas, as quais expressam já tardiamente como definha o que ainda resta de tal sentido "aurático" que acompanha o cinismo de 
seu valor de exposição, passando-se por uma negação meramente imaginária do que ainda persiste dele. Semelhantes formas denunciam o estado presente, "no mundo desencantado [entzauberten], sem que ele o admita, o factum da arte, imitação do mágico [Zaubers], é um escândalo que não suporta" (ADORNO, 1983, p. 74; 1977 [AGS 7], p. 93). Esse factum, o destino que não suporta, evidencia-se ainda mais hoje diante das novas possibilidades técnicas que não podem ser dominadas por um só sujeito, quando o desencantamento da arte se dá nesse duplo sentido.

De modo semelhante a Weber, os aspectos inequívocos do progresso nas pinturas e nas composiçóes musicais aparecem justapostos, no texto de Adorno (1983, p. 239): “[...] os materiais históricos e o seu domínio, isto é, a técnica, progridem de modo incontestável; descobertas como as da perspectiva na pintura, da polifonia na música são disso os exemplos mais evidentes”. Vemos, na Teoria da Estética, uma clara menção à diferença estabelecida no escrito sobre o progresso, mas com alteraçóes no exemplo da música. Adorno afirmava, por um lado, que, "sem dúvida, é possível desvendar em Bach as lacunas entre a estrutura da sua música e os meios técnicos outrora disponíveis para a sua execução plenamente adequada", porém, por outro lado, ressaltava que

[...] é vão decidir qual dos efeitos da pintura pré-perspectivista é devido à profundidade do expresso ou a uma stéresis da insuficiência técnica, que sempre se transforma em expressão. Nas obras arcaicas, que geralmente não são amplas mas restritas na sua possibilidade, parece haver tanta técnica, e não mais, quanta a que lhe é necessária para a realização da coisa. Isso confere-lhes aquela enganosa autoridade que ilude sobre qual aspecto técnico foi condicionante e possuidor de semelhante autoridade (ADORNO, 1983, p. 75; 1977 [AGS 7], p. 97).

Nesse escrito, o contraste se revela mais claro que no exemplo do texto de 1962, porque o reconhecimento de suas possíveis soluçôes, ante à limitação das lacunas ou simples privação de uma técnica, permite ver o caso limítrofe da música com imperativos da técnica que se deram em stricto sensu, não apenas pela natureza dos objetos, mas do sentido mais unívoco de sua racionalizaçáo. Uma expóe seu limite por lacunas, outra a preenche com formas distintas.

Essas passagens poderiam ser revisadas e verificadas pelo método analítico weberiano; seria possível separar cada sentido do progresso nelas contido e, talvez, não seria por isso destruído o sentido histórico nelas presente, o qual passaria por uma revisáo supostamente isenta (wertfrei) de valoraçóes 
estéticas. Verificar-se-ia que seria impossível chegar a essas conclusóes, tomando semelhante procedimento conceitual da teoria tradicional como ponto de partida, pouco ou nada concluiríamos sobre o sentido de seu progresso, além da diferenciação ou descrição meramente formal da alteração das técnicas. Mas Weber nunca tomou esses procedimentos tấo a rigor, de maneira que a formação de seus conceitos sociológicos foi quase sempre produzida $a$ posteriori, não nas premissas (ADORNO, 2007, p. 288-289).

Era justamente essa falha no ponto de partida conceitual que Adorno expunha ao início de seu escrito, ao afirmar que "o conceito de progresso se desfaz com ainda mais facilidade que os demais diante da exigência de especificação daquilo que realmente quer dizer". Quanto ao critério de isenção valorativa de Weber, náo identificaríamos qualquer veto evidente, podendo sua posição, do mesmo modo que sua sociologia da música, se mostrar útil, tanto para o esteta como para o historiador da arte - e assim foi.

Contudo, esse elemento teórico mais irrepreensível é o que manifestaria o maior dano ao propósito crítico; o posicionamento teórico faria a interpretação ocultar a limitação subjetiva real de seu nexo histórico e, nele, a capacidade crítica estaria mais lesada, pois estaria reduzindo o espectro de seu objeto, sem sentir que algo lhe falta, julgando eliminar um mero juízo de gosto, achando-se em meio a seu pleno domínio teórico-científico pelo primado do sujeito de que parte. $\mathrm{O}$ esforço crítico da teoria tradicional indispóe-se, sem saber, contra a pretensão de problematizar historicamente seu objeto para além dessas condiçôes aparentemente teóricas e técnicas - "eles não sabem, mas o fazem”. A confusão das consideraçôes de Adorno com juízos de gosto lhe rendeu e rende até hoje intermináveis críticas, fruto da incompreensão da relação dialética entre sujeito e técnica (DAHLHAUS, 1970, 1987) ${ }^{18}$. Semelhante estado de espírito reduz a crítica de Adorno a juízos estéticos.

Essa postura limitadora da crítica afetava a interpretaçáo de Weber, a ponto de aproximá-lo das limitações fatalistas da decadência, embora transmutasse o que nela era mera opinião em uma conclusão mais comedida e pontual, temperando qualquer efeito de posiçóes mais exacerbadas, cortando suas arestas, seus excessos retóricos, todavia, no fim, produzia a mesma subserviência ao destino ligado ao primado da técnica que parece estar sobre

\footnotetext{
${ }^{18}$ Nesse sentido, seguiu-se a análise sistemática de Richard Klein (2009), o qual aponta como Dahlhaus analisou a fundo a teoria musical adorniana, compreendendo inclusive o sentido de sujeito de que tratamos, mas remetendo a essa questão como "filosófica", indisposto a reconhecer seu real sentido histórico-dialético, sentido visado nesta pequena contribuição à discussão.
} 
as forças humanas. Entre os experts na teoria musical, não faltaram críticos de Adorno que confundem seu diagnóstico histórico sobre a condição subjetiva das produçôes estéticas com uma questão de gosto.

Ambas as formas limitadas de consciência são sintomas de que o progresso continua a se realizar por meio desses "objetos" alheios a qualquer propósito e, justamente por isso, o sujeito se reduz a mero intérprete e expectador, que, como tal, busca controlar sua indignaçáo com os ares do historiador que já viu de tudo, e nada o fez concluir ser mais que espectador dos fenômenos, não tendo motivo para se alarmar nem se entusiasmar. "É o destino de nosso tempo", dizia Weber, "nós tentamos 'inventar' e forçar uma convicção artística monumental, tão logo surgiram essas lamentáveis deformidades, tal como ocorreram em muitos dos monumentos dos últimos vinte anos" (1922 [GAWL], p. 554); exceto por esse caráter de "destino", de resto, essa opinião se mostraria bastante próxima da crítica de Adorno ao ideal da Gesamtkunstwerk, obra de arte total wagneriana (ADORNO, 1986 [AGS 13], p. 26-27).

Também nas notas de Weber do livro de Simmel, Schopenhauer e Nietzsche, encontra-se um comentário no qual Weber afirma que Nietzsche seria, ele próprio, não mais que um filisteu (SCHLUCHTER, 1996. p. 282), e não é difícil imaginar por que Weber chegou a semelhante conclusão. $\mathrm{O}$ sujeito idealizado na interpretação de Weber parece o produto de um estado de espírito burguês que ainda náo se reconhece com tal; apesar de estar farto das produçôes culturais de sua época, já não mais adere, relutante, à postura de um filisteu. Esse é o pathos que ele próprio não consegue depurar criticamente e nem remover de sua análise do progresso; é útil à interpretação histórica exata, pois diz muito historicamente do ponto de vista do presente, já que vemos nele o ideal alemáo da Bildung caminhando para um sentido pós-romântico.

ROSELINO, L. F. S. Max Weber and Adorno on the concept of progress: contrasts of technical rationalization in music and painting. Trans/form/ação, Marília, v. 43, p. 301-340, 2020. Edição Especial. 


\begin{abstract}
This review will develop a theme from the theoretical contrast between Max Weber and Adorno approach of the concept of "progress", read by their discussions on respectively, "The Meaning of Wertfreiheit in Sociology and Economics" (1917) and "Fortschritt", (Progress, 1962). After establishing a comparison between both writings and their theoretical tools, we shall identify the differences in resources by the critical and traditional theory elements. The opposition shall become more distinctly as the comparison reach the historical examples from their readings on Art History. Weber has employed a general bias to equate musical productions and painting, as Adorno, on the other hand, forecast something quite different as he followed the same guideline, the technical progress.
\end{abstract}

Keywords: Adorno. Max Weber. Progress. Aesthetic. Music.

\title{
REFERÊNCIAS
}

ADORNO, T. Ästhetische Theorie In: Theodor W. Adorno: Gesammelte Schriften, Bd.7 Frankfurt/Main: Suhrkamp. 1977, p. 7-387.

ADORNO, T. Fortschritt In: Theodor W. Adorno: Gesammelte Schriften, Bd.10.2, Frankfurt/Main: Suhrkamp. 1977, p. 617-638.

ADORNO, T. Introduçáo à sociologia. (Tradução: Wolfgang Leo Maar). São Paulo: Ed. UNESP, 2007.

ADORNO, T. Sobre algunas relaciones entre música y pintura In: Escritos Musicales I-III. Madrid: Ediciones Akal, 2006, p. 637-649

ADORNO, T. Teoria Estética. Lisboa: Edições 70 Ltda, 1983.

ADORNO, T. Versuch über Wagner In: Theodor W. Adorno: Gesammelte Schriften, Bd.13 Frankfurt/Main: Suhrkamp. 1986, p. 7-145.

BENJAMIN, W. O Anjo da História. Belo Horizonte: Autêntica Ed. Ltda. 2012.

BENJAMIN, W. A obra de arte na época de suas técnicas de reproduçáo In: Coleção Os Pensadores. São Paulo: Abril Cultural, 1975, p. 9-34.

DAHLHAUS, Carl. Das Problem der öheren Kritik. Adornos Polemik gegen

Strawinsky. Neue Zeitschrift für Musik v. 148, 1987, p. 9-15.

DAHLHAUS, Carl. Soziologische Dechiffrierung von Musik. Zu Theodor W. Adornos Wagnerkritik." In: The International Review of Aesthetics and Soziologie of Music. 1, 1970, p. 137-146.

DUARTE, Ricardo. Sobre o conceito de "pseudomorfose" em Theodor Adorno. Artefilosofia, n.7, 2009, p. 31-40.

HABERMAS, Jürgen. Theorie des Kommunikativen Handelns. Frankfurt: Suhrkamp, 1988. 
KLEIN, Richard. Philosophische Kritik als Problem der Musikwissenschaft. Zur AdornoRezeption bei Carl Dahlhaus am Beispiel des Versuch über Wagner. In: Andreas Dorschel (Org.), Kunst und Wissen in der Moderne, Viena: Böhlau, 2009, p. 105-121.

MAAR, Wolfgang. Materialismo e primado do objeto em Adorno In: Trans/Form/ Ação, São Paulo, 29(2), 2006, p. 133-154.

MUSSE, Ricardo. Elementos da crítica de Adorno a Kant. Doispontos, Curitiba, São Carlos, vol. 4, n. 1, 2007, p. 201-215.

MARX, Karl. Misère de la philosophie. Paris: V. Giard \& E. Brière. 1896.

OLLMAN, Bertel. Alienation. Marx's Conception of Man in Capitalist Society. New York: Cambridge Un. Press, 1973.

SCHLUCHTER, W. Unversöhnte Moderne. Frankfurt: Suhrkamp, 1996.

SOCHA, Eduardo. Lessing na estética de Adorno: Música, Pintura e a questão da pseudomorfose. Trans/Form/Açáo, Marília, v. 42, n. 3, 2019, p. 91-118.

WEBER, Max. Gesammelte Aufsätze zur Wissenschaftslehre. [GAWL] Tübingen: J.C.B. Mohr. 1922.

WEBER, Max. Diskussionsrede zu W. Sombarts Vortrag über Technik und Kultur auf dem ersten Deutschen Soziologentage in Frankfurt (1910)" In: Schriften der Deutschen Gesellschaft für Soziologie. Vol. I, Tübingen: Mohr Siebeck 1911, p. 95-101.

Recebido: 25/10/2019

Aceito: 17/02/2020 